\title{
Does quality institutions promote environmental quality?
}

\author{
Hamisu Sadi Ali ${ }^{1}$ • Veton Zeqiraj ${ }^{2}$. Woon Leong Lin $^{3}$ • Siong Hook Law ${ }^{4} \cdot$ Zulkornain Yusop $^{4}$. \\ Uweis Abdulahi Ali Bare ${ }^{4}$. Lee Chin ${ }^{4}$
}

Received: 2 January 2018 / Accepted: 21 February 2019 / Published online: 19 March 2019

(C) Springer-Verlag GmbH Germany, part of Springer Nature 2019

\section{Introduction}

The dynamic relationship between carbon dioxide emissions and other macroeconomic variables is long established in the literature, and carbon dioxide is seen as one of the variables that captures the environmental conditions in the global economy. The manufacturing sector plays a key role in the economic growth of every nation. However, its operation is attached to carbon dioxide emissions, which are perceived to be one of the main causes of environmental harm that can seriously affect and reduce the environmental quality. Achieving a higher level of economic growth is believed to fall in line with higher environmental degradation (Sharma 2011), as higher economic activities may promote more environmental problems. Hence, a political instrument for viable development is introduced here with the goal of balancing the concept of economic development, environmental degradation, and social fairness. Sound and quality environmental policies in an economy could be one of the key determinant factors for improving environmental quality (Ibrahim and Law 2015). Thus, quality institutions should be considered as inputs for providing sound legislation that when applied efficiently will help reduce environmental menace in the global economy

Responsible editor: Philippe Garrigues

Hamisu Sadi Ali

hamisusadi@gmail.com

1 Department of Economics, Faculty of Social Sciences, Ahmadu Bello University Zaria, Zaria, Kaduna 1044, Nigeria

2 Faculty of Economics, University of Prishtine, pn. 10000, St. Agim Ramadani, Pristina, Kosovo

3 Department of Management and Marketing, Faculty of Economics and Management, Universiti Putra Malaysia, 43400 Serdang, Selangor, Malaysia

4 Department of Economics, Faculty of Economics and Managemen, Universiti Putra Malaysia, 43400 Serdang, Selangor, Malaysia
(Lau et al. 2014). Environmental degradation is presently disturbing the global economy, and considering its adverse effects has caused various governments to budget hugely to control the hazards. Without these environmental problems, the resources earmarked to control related environmental problems could be used to achieve other important economic objectives.

This study investigated the impact of institutional quality on environmental quality in the developing countries. Several studies were conducted on environmental degradation and its determinants. However, little is still known about the roles of institutions in reducing environmental problems. This study is different from the existing literature in three ways; first, most of the studies in this area focus more on growth, financial development, and trade openness, and little attention is given to environmental policy aspects; this is the main focus of this current paper. Second, a lot of attention has been given to the developed countries, thereby ignoring the developing countries where the problems are also/even more evident. Carbon dioxide emissions are the major cause of global warming which deteriorates overall environmental condition by depleting the ozone layer and hence affecting the health of the general populace as well. Carbon emissions from the developing countries will surpass those of the developed countries in the Organization for Economic Co-operation and Development (OECD) over the next three decades due to their higher rate of economic growth in those countries and their continuous use of fossil fuels. Part of the reason for choosing developing countries to study is based on the projection that energyrelated carbon dioxide emissions from those countries will be $127 \%$ higher than emissions in the advanced economies by 2040 according to the U.S. Energy Information Administration (EIA 2016).

The world map in Fig. 1 shows the distribution of lessdeveloped countries as shown by the green color; this highlights majority of the countries in the global economy fall under the category of developing countries. Despite several studies that have examined the relationship between carbon 


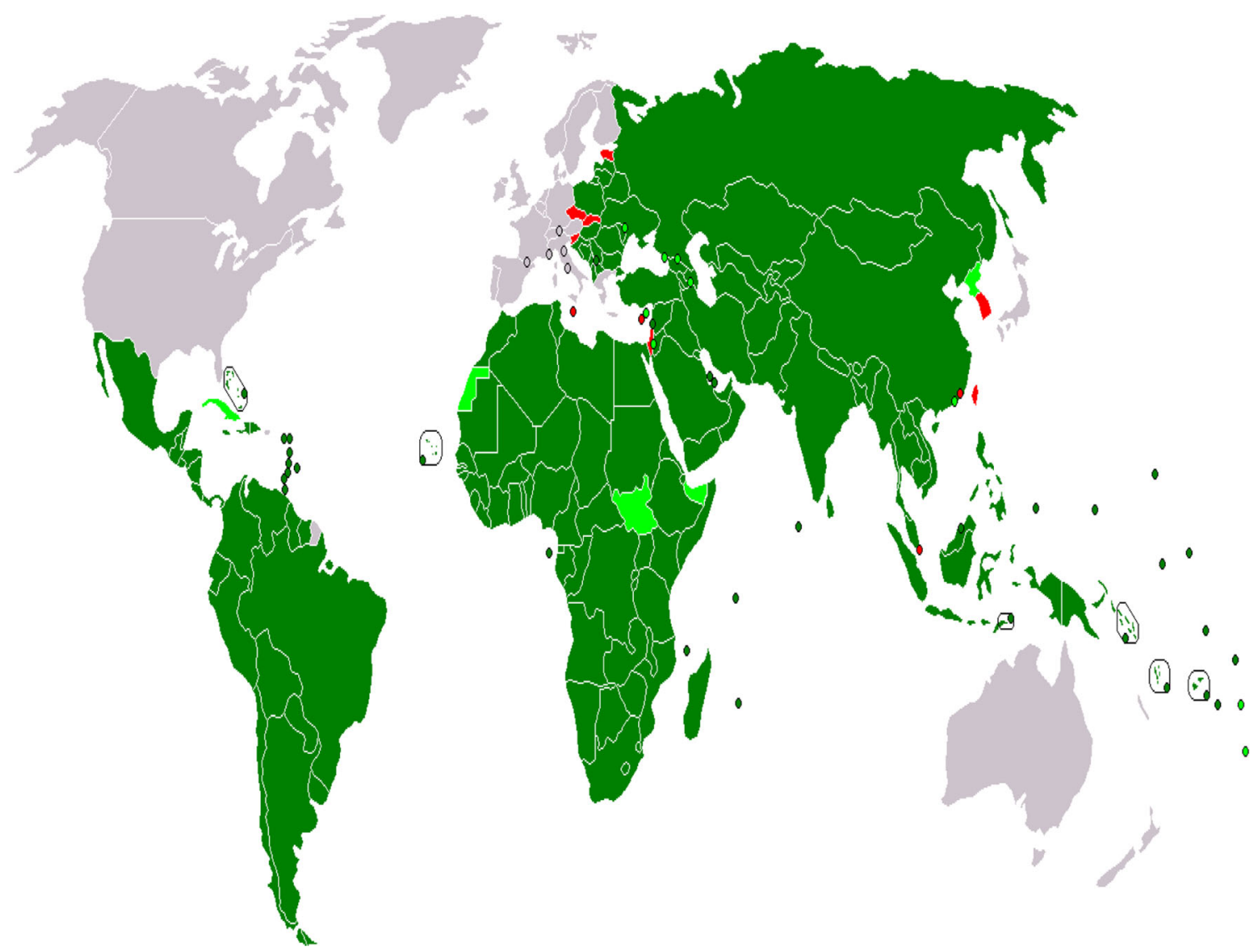

Fig. 1 World map showing the distribution of developing countries

dioxide emissions and other variables, very few studies have related carbon dioxide emissions to the quality of the institutions that are providing an efficient regulatory framework to safeguard overall environmental degradation. The rest of this study is structured as follows: "Conceptual framework section" highlights on the conceptual framework that relate institutions and environmental quality. "Literature review section" focuses on the review of the previous related literatures. "Econometric methodology and the empirical model section" highlights on the discussions of the models and methodology used in the study (generalized method of moments). Moreover, the data used in the study, measurement of the variables, and the data sources were also highlighted in this section. "Empirical results and discussions section" discusses the empirical results, and "Robustness checks section" highlighted the robustness checks of the main findings. Lastly, "Conclusion and policy recommendations section" summarizes the findings and recommends policy suggestions based on the study outcomes.

\section{Conceptual framework}

Institutions could be conceptualized as a composition of rights, rules, and decision-making processes which is taking place through the levels of social organizations that give more emphasis on environmental conditions and resource regimes. Maximum human security is attained when individuals and societies aimed to reduce threats to human lives and promote environment and social rights. From Fig. 2, economic growth affects environmental degradation which is basically known as Environmental Kuznets Curve (EKC). Institutional quality

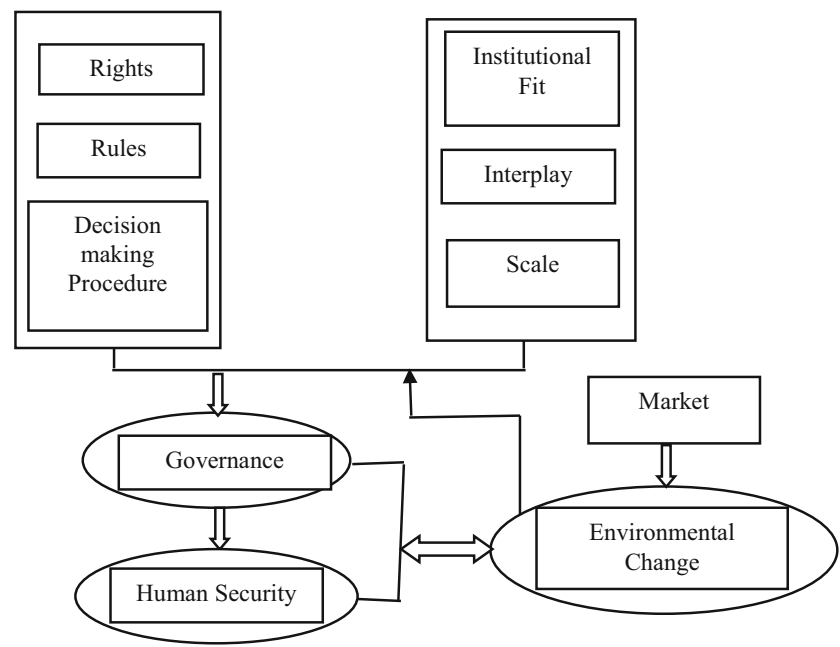

Fig. 2 Conceptual framework of the institutions and environmental quality. Source: adopted from Egbetokun and Ogundipe (2016) 
can accelerate the curve to move and attain a turning point faster than its normal pass through to achieve desired sustainable growth. Vibrant institutions can influence economic growth and environmental degradation by suitably guaranteeing the location of polluted industries that may control pollution haven. Furthermore, intervention of institutions can promote rapid economic growth which may result in the increase of environmental degradation that can also be checked by the institutions through proper legislation.

\section{Literature review}

There are a number of studies that relate carbon dioxide emissions to other macroeconomic variables and their numerous results. Carbon dioxide emissions are considered one of the reliable measures of the environment and its quality in the global economy. Therefore, it is used by different researchers in the fields of environmental sciences and environmental economics. However, since the studies on this research segment are not much, we reviewed the literature on both the impacts of economic growth on environmental performance, impact of trade openness on the economy and environmental performance, pollution haven hypothesis, and institutional quality and environmental performance. For example, in their quest to test the pollution haven hypothesis, Dean et al. (2009) estimate the behavior of the factors that affect the location choice for equity joint ventures (EJVs) in China. They used theoretical firm framework of production and abatement decision and derive a location choice model based on data of a sample of EJV projects, Chinese efficient charges on water pollution, and Chinese industrial pollution intensity. The empirical finding reveals that poor environmental policies attracted the funding of EJVs in Hong Kong, Macao, and Taiwan. However, EJVs that are financed from non-ethnically Chinese basis are insubstantially attracted by the poor standards irrespective of the level of pollution of the industry.

Pao and Tsai (2011) examined the impact of economic growth and financial development on environmental condition based on panel co-integration approach during 1980 to 2007 except Russia that the time period ranges from 1992 to 2007 across BRIC economies. The result in the long run reveals that carbon dioxide emissions show that energy consumption is elastic and FDI is inelastic. The result further highlights that bidirectional causality exists between carbon dioxide emissions and FDI, and a unidirectional causal relationship exists that run from output to FDI. Hence, this research outcome supports pollution haven hypothesis. Zeng and Eastin (2012) investigated the impact of direct investment (FDI) on environmental condition in developing countries. The main empirical result shows that production of the firms in the host countries in the form of FDI enhances the environmental quality in the countries studied. Arouri et al. (2012) based on 12 Middle East and North African (MENA) countries for the period of 1981-2005 examined the nexus between carbon dioxide emissions, energy consumption, and economic growth. The empirical result shows that consumption of energy has a positive and substantial impact on carbon dioxide emissions. The result also shows that economic growth reveals a quadratic association with the level of carbon dioxide emissions in the sample countries.

Lau et al. (2014) examined the impact of quality institutions and carbon dioxide emissions on economic growth in Malaysia for the period 1984-2008, using the bound testing approach. Its co-integration results showed that variables have a long-term relationship. That means that the variables of institutional quality, carbon emissions, and exports have a positive and significant impact on economic growth. When the variables of carbon dioxide emissions and institutional quality interact, the result also remained positive and significant for economic growth. This finding means that quality institutions can work toward the reduction of carbon dioxide emissions effectively, and hence enhance environmental quality while improving economic development. The Granger causality tests additionally ratified the contributions of institutional structures in reducing carbon dioxide emissions, institutional quality influences economic growth both directly and indirectly through the ongoing increased reduction of carbon dioxide emissions.

Ibrahim and Law (2015) examined the effect of trade, institutional quality, and their marginal effects on carbon dioxide emissions in 40 Sub-Sahara African countries. They applied the system generalized method of moments (system GMM). The result revealed that the effect of trade on the environment was dependent on the quality of the institutions in these countries. Indeed, trade openness negatively affected environmental quality in those countries with poor institutions and tended to benefit those countries with better quality institutions that were sound. Therefore, for those countries with poor institutions to gain the benefits of a positive environmental effect on trade, they must reform their institutions to deliver effective performance. Merican (2007) investigated the impact of foreign direct investment (FDI) on the pollution in five ASEAN nations, namely, Malaysia, Thailand, Indonesia, Singapore, and the Philippines based on the ARDL estimation technique. The main finding revealed that FDI promotes environmental degradation through the escalation of high pollution in the environments of Malaysia, Thailand, and the Philippines. However, FDI was inversely related with pollution in Indonesia and had no significant impact on pollution in Singapore. Ren et al. (2014) applied system GMM and examine the dynamic impact of FDI, trade openness, exports, imports, and per capita income on carbon dioxide emissions during 2000-2010 in China. The main empirical finding shows that increase in the China's trade sector surplus 
positively influences rapid increase in the carbon dioxide emissions in the country. Also, high inflow of FDI into the country aggravate carbon dioxide emissions into the country and the per capita income and China's industrial output nexus shows an inverted U-shaped which support environmental Kuznets curve in the country.

The relationship between economic growth, electricity consumption, urbanization, and environmental degradation was examined by Shahbaz et al. (2014). They utilized the autoregressive distributed lags (ARDL) approach for the period 1975-2011 in the United Arab Emirates (UAE). The finding showed that variables are actually related in the long term. An inverted U-shaped relationship, i.e., the Environmental Kuznets Curve (EKC) exists between economic growth and carbon dioxide emissions. This finding means that initially growth increases energy consumption upwards to a given limit of income after which growth reduces it. Electricity consumption leads to a decline in carbon dioxide emissions, while urbanization enhances those emissions. Exports increase environmental quality via a reduction of carbon dioxide emissions. The results also reported a feedback effect for carbon dioxide emissions and electricity consumption, while urbanization and economic growth led to more carbon dioxide emissions. Ponce de Leon Barido and Marshall (2014) investigated the impact of urbanization and environmental policy on carbon dioxide emissions for a sample of 80 countries. They applied fixed and random effect techniques for the period 1983-2005. The findings showed that on average, a $1 \%$ increase in urbanization could cause carbon dioxide emissions to increase by $0.95 \%$. Researching 129 countries, Al-mulali et al. (2015a) examined the dynamic impacts of urbanization, economic growth, trade openness, petroleum consumption, and financial development on carbon dioxide emissions. The heterogeneous panel estimation technique was applied for the period 1980-2011. A Pedroni cointegration result revealed that variables have a long-term relationship, while DOLS and Granger causality showed that financial sector development promotes environmental quality in the short run and the long run, hence reducing carbon dioxide emissions. Petroleum consumption was found to be the key source of environmental degradation for most income groups.

Disaggregated renewable electricity production and a carbon dioxide emission nexus was examined by Al-mulali et al. (2015b) for a sample of 23 European countries for the period 1990-2013. Panel co-integration analysis technique was applied. The Pedroni co-integration result shows that carbon dioxide emissions, GDP growth, urbanization, financial development, and renewable electricity production are co-integrated. Based on a fully modified ordinary least square (FMOLS), the finding shows that financial development, economic growth, and urbanization increases carbon dioxide emissions in the long term. However, trade openness reduces carbon dioxide emissions. Al-mulali and Ozturk (2015) applied a panel co-integration analysis technique across 14 MENA countries and examined the causes of environmental degradation in the region for the time period 1996-2012. The Pedroni co-integration test revealed that the variables have long-term relationship. Moreover, the result of FMOLS showed that energy consumption, urbanization, trade openness, and industrial development causes environmental degradation, while political stability decreases it. The result of the Granger causality showed that the variables have both a longrun and a short-run causality with the ecological footprint.

The dynamic impact of economic growth, $\mathrm{CO}_{2}$ emissions, and foreign direct investment was investigated by Balibey (2015). The goal was to evaluate the environmental Kuznets curve hypothesis for Turkey for 1974-2011. The study used Johansen co-integration, Granger causality tests, and impulse response as well as a variance decomposition analysis of the vector auto-regression model (VAR) models. The finding, which based on causality, revealed that FDI and economic growth positively influence carbon dioxide emissions. The findings based on impulse response function and variancedecompositions also supported the same relationship between these variables. Asongu et al. (2016) used panel ARDL technique to examine the relationship between energy consumption, carbon dioxide emissions, and economic growth across 24 African countries. The main finding confirms the existence of long-run relationship between energy consumption, carbon dioxide emissions, and economic growth. Moreover, the short-run error correction model (ECM) is negative, significant and less than one as theoretically required. Salahuddin et al. (2015) applied fully modified ordinary least square (FMOLS), dynamic ordinary least squares (DOLS), and dynamic fixed effect model (DFE) during 1980 to 2012 across Gulf Cooperation Council (GCC) countries and examine the impact of economic growth, electricity consumption and financial development on carbon dioxide emission. The main empirical finding shows the existence of positive and long-run relations between electricity consumption, economic growth, and carbon dioxide emissions. However, a negative and significant relationship exists between financial development and carbon dioxide emissions. The result further shows that electricity consumption and economic growth stimulates carbon dioxide emissions; however, development of the financial sector reduces environmental degradation in the sample countries.

Ozturk (2015) applied panel co-integration approach during 1990-2012 and empirically examined the nexus between energy consumption, air pollution, and climate change across the panel of six economically diversified nations. The pooled OLS result signifies that energy consumption and air quality have positive and substantial impact on climate change. The result further highlight that $1 \%$ increase in energy consumption raises the emission of greenhouse gases by $0.124 \%$, 
carbon dioxide emissions by $0.652 \%$, methane emissions by $0.123 \%$, and nitrous oxide emissions enhance greenhouse gas emissions by $0.105 \%$. However, the fixed and random effect regression result proved the weakening of air quality indicators on climate change. Seker et al. (2015) applied autoregressive distributed lag (ARDL) and examined the impact of foreign direct investment (FDI), economic growth, and consumption of energy on carbon dioxide emissions in Turkey during 1974-2010. The finding reveals that there is a long-run relationship among the variables. Moreover, the ARDL longrun coefficient shows that the impact of FDI on carbon dioxide emissions is found to be positive although is relatively small. However, its effects on economic growth and energy consumption are quite substantial. Furthermore, the short-run result also reconfirmed that of the long run. Farhani and Ozturk (2015) empirically investigate the causality between carbon dioxide emissions, energy consumption, trade openness, financial development, economic growth, and urbanization in Tunisia during 1971-2012. They applied ARDL approach and examine the long-run relationship among the variables. The main empirical result shows that financial development increases the level of carbon dioxide emissions. The finding also reveals the presence of positive and monotonic relationship between economic growth and carbon dioxide emissions in the country. This result does not support the validity of environmental Kuznets curve (EKC) hypothesis.

Ali et al. (2016) applied ARDL and empirically examined the dynamic impact of urbanization on environmental condition in Nigeria during 1971-2011. The long-run result shows that variables have long-run relationship as null hypothesis was rejected. Moreover, the coefficient of long-run result shows that urbanization does not have any substantial impact on environmental quality in Nigeria. The result further reveals that energy consumption and economic growth have positive and significant impact on environmental condition in Nigeria, while trade openness reduces the level carbon dioxide emission which directly improves the quality of environment. Zhang and Zhou (2016) empirically examined the impact of foreign direct investment (FDI) on carbon dioxide emissions during 1995 to 2010 across regional and national level in China. They applied Stochastic Impacts by Regression on Population, Affluence, and Technology (STIRPAT) model. The main empirical finding reveals that FDI increases environmental quality through reduction in the level of carbon emissions in China. Moreover, the result shows that FDI reduces carbon dioxide emissions in the western region to the eastern and central regions. Hence, their finding supports pollution haven hypothesis in the case of China. Alam et al. (2016) investigates the dynamic impact of energy consumption and population growth on carbon dioxide emissions based on autoregressive distributed lag (ARDL) bound test during 1970 to 2012 across India, Indonesia, China, and Brazil. The main empirical finding show that increase in income and energy consumption triggers carbon dioxide emissions in the sample countries. However, the link between carbon dioxide emissions and population growth is statistically substantial in the case of India and Brazil, while same relationship remains statistically insignificant in the case of China and Indonesia in the short run and long run. Moreover, they tested environmental Kuznets curve (EKC) hypothesis which reveals that increases in the level of income in Brazil, China, and Indonesia reduce the level of carbon dioxide emissions.

Ali et al. (2017) empirically examined the dynamic impact of urbanization on environmental quality in Singapore being the most urbanized country in the world with $100 \%$ of its populace living in the urban center. The main empirical finding suggests a negative and significant impact of urbanization on carbon dioxide emissions in the country. This means urbanization is not a barrier to the environmental condition in the country. However, economic growth deteriorates environmental quality through incessant increase of the carbon dioxide emissions. Paramati et al. (2017) applied different robust panel econometric techniques during 1990-2012 and examine the impact of renewable energy consumption on output and carbon dioxide emissions of the succeeding fastest developing countries in the globe. The main empirical result reveals the presence of long-run relationships among the variables. Moreover, renewable energy consumption has a positive and significant impact on output and has a negative and significant impact on carbon dioxide emissions in the sample countries.

Ahmed et al. (2017a) empirically examine the impact of energy consumption in relation to carbon dioxide emissions and trade integration across eight (8) countries in the ASEAN sub-region. The main empirical finding reveals that environmental cost of economic growth is disturbing for most of the panel member countries. The result further highlight that nonrenewable energy consumption is the main contributing factor that deteriorate environmental quality in the ASEAN sub-region. Salahuddin et al. (2017) applied autoregressive distributed lag (ARDL) bounds testing econometric technique in Kuwait and examine the dynamic impact of economic growth, electricity consumption, foreign direct investment (FDI), and financial development on carbon dioxide (CO2) emissions. The study period is 1980-2013. The key finding reveals that economic growth, FDI, and electricity consumption have a positive and significant impact on carbon dioxide emission in both short and long run. However, VECM Granger causality result shows that FDI, economic growth, and electricity consumption strongly Granger-cause carbon dioxide emissions in Kuwait.

Ahmed et al. (2017b) empirically investigated the nexus between carbon dioxide emissions and four of its main contributing factors which includes population, trade openness, energy consumption, and income. They applied fully modified 
ordinary least square (FMOLS) analysis during 1971 to 2013 across five South Asian countries. The main empirical finding reveals that energy consumption, trade openness, and population stimulate carbon dioxide emissions. This means these three variables reduce environmental quality of the sample countries. The result however shows that income has a negative impact on environmental degradation. They went further and applied innovative accounting approach to examine the causality among the variables. The causality result shows bidirectional causality between energy consumption and trade openness. However, the unidirectional causality exists running from energy consumption, trade openness, and population to carbon dioxide emission.

Sinha et al. (2017) empirically examined the dynamic impact of environmental Kuznets curve (EKC) for carbon dioxide emissions across 11 economies during 1990-2014. This study segregates three different forms of energy (renewable, biomass, and non-renewable) and incorporates urbanization and level of openness in trade. The main empirical finding based on generalized method of moments reveals that the presence of $\mathrm{N}$-shaped relationship between economic growth and environmental degradation across the sample countries. They went further to analyze the interaction effect among biomass energy consumption, trade openness, and economic growth. The result shows a negative impact on carbon dioxide emissions for the sample countries. In summary, it is deduced that most of the literature reviewed above highlight that quality institutions enhances environmental quality, for example, Lau et al. (2014), Ibrahim and Law (2015), and Al-mulali and Ozturk (2015).

\section{Econometric methodology and the empirical model}

The key objective of empirical specification is to explain the stages of carbon dioxide emissions and its variations across different countries. This goal is based on an empirical model that allows testing of the main hypothesis regarding. The empirical model will be the determinant for using time and various country measurements of the annual dataset for that estimation. Since the study data is annual, the likelihood of not learning long-run equilibrium values should be provided due to the slow adjustment of the regressors. The dynamic loglinear equation of carbon dioxide emissions that has a lagged dependent variable is estimated to allow room for partial adjustment. To achieve the study objective, the following loglinear equation is specified for carbon dioxide emissions:

$$
\begin{aligned}
\operatorname{LCEM}_{i t}= & \alpha_{0 i}+\gamma \operatorname{LCEM}_{i t-1}+\alpha_{1} \mathrm{LINQ}_{i t}+\alpha_{2} \mathrm{LY}_{i t} \\
& +\alpha_{3} X_{i t}+\eta_{t}+\lambda_{i}+\varepsilon_{i t}
\end{aligned}
$$

where LCEM is the log of carbon dioxide emissions, $\gamma \operatorname{LCEM}_{i t-1}$ is the lagged dependent variable of carbon dioxide emissions, LINQ is the log of institutional quality, LY is the $\log$ of economic growth, and $X$ is the vector of the other control variables [financial development (LFD), trade openness (LTO), urbanization (LUB), and energy consumption (LEC)]. While $\eta_{t}$ indicates the time specific fixed effect, $\lambda_{i}$ shows country specific effect, $i$ denotes country, and $t$ represents the time period. The full specification of the model is shown using Eq. (2) below:

$$
\begin{gathered}
\operatorname{LCEM}_{i t}=\alpha_{0 i}+\gamma \operatorname{LCEM}_{i t-1}+\alpha_{1} \operatorname{LINQ}_{i t}+\alpha_{2} \mathrm{LY}_{i t}+\alpha_{3} \mathrm{LFD}_{i t}+\alpha_{4} \mathrm{LTO}_{i t}+\alpha_{5} \mathrm{LUB}_{i t}+\alpha_{6} \mathrm{LEC}_{i t}+\eta_{t}+\lambda_{i}+\varepsilon_{i t} \\
i=1 \ldots 47 \text { and } t=1, \ldots \ldots ., 7
\end{gathered}
$$

\section{Dynamic panel GMM estimation}

The presence of a lagged-dependent variable can cause a correlation between the regressors and the error term because the lagged-dependent variable depends on $\mu_{i t-1}$ which also depends on the country-specific effect $\left(\mu_{i}\right)$. When Eq. (1) is estimated, it may suffer from Nickell (1981) bias which then vanishes, as T approaches infinity. To correct such biasness in the estimation, one must apply either the generalized method of moments (GMM) proposed by Arellano and Bond (1991) or use system GMM by Arellano and Bover (1995). Based on these techniques, when the first difference is taken in the models, the country- and time-specific effects and the simultaneity bias problem is removed. The assumption is that the original disturbance term in Eq. (1) $v_{i t}$ does not correlate with the differenced errors. In order to test the validity of the estimated parameters, post-estimation tests of the first and second order serial correlation is conducted. The condition indicates that the null hypothesis for the first order serial correlation can be rejected, but for the second order, serial correlation cannot be rejected.

Furthermore, the Sargan test is applied to test overidentification restriction because of too many moment conditions. Still, an increase in the efficiency of estimation may lead to estimation bias. It is thus recommended by Baltagi (2005) that a subset of these moment conditions should apply in order to gain from the trade-off of increased efficiency and reduced estimation bias. The sample countries used in this study were Angola, Algeria, Azerbaijan, Albania, Armenia, Bangladesh, Belarus, Botswana, Brazil, Bulgaria, Bolivia, Cameroon, Congo Dep., Colombia, Costa Rica, Dominican Republic, Ethiopia, Egypt Arab Republic, Ghana, Guatemala, Gabon, Haiti, Honduras, India, Indonesia, Jordan, Kosovo, Kenya, Malaysia, Mozambique, Moldova, Mongolia, Morocco, 
Mexico, Namibia, Nigeria, Nicaragua, Pakistan, Paraguay, the Philippines, South Africa, Sri Lanka, Tanzania, Togo, Thailand, Turkey, and Venezuela RB. These ranges of countries were selected based on their characteristics of having largely poor institutional performance, which may also include improper environmental regulations when compared to the advanced industrialized nations like the United States of America (USA), Germany, Spain, Japan, and France.

The 47 countries were also selected based on their similar characteristics of falling into the category of developing countries. Secondly, the level of bureaucratic quality and rule of law is still very low and corruption is high when compared to advanced countries. For example, the average point most of the developing countries scored in the international country risk guide (ICRG) data base related to bureaucratic quality is $2 \%$, same is also applicable to the rule of law. However, in the case of the corruption index which shows that countries that score higher points experience little corruption, e.g., the United States of America (USA) and the United Kingdom (UK) scored 5 points on average. Most of the developing countries average score is 2 points which highlight the extent of corruption in those countries. Moreover, the current level of carbon dioxide emissions globally is mainly concentrated in the advanced industrialized nations; yet, it is strongly projected that in the next few years, that trend will move toward the developing countries (U.S. Energy Information Agency). Therefore, examining that linkage with the quality of institutions in the developing countries is paramount.

\section{The data}

The data used for this study across 47 developing countries was obtained from two different sources and carbon dioxide emissions as proxied by $\mathrm{CO}_{2}$ emissions metric tons per capita was obtained from the World Development Indicators data set (WDI). The variable of institutional quality was obtained from the International Country Risk Guide (ICRG) in which three political risk services (PRS) variables, namely, corruption, rule of law, and bureaucratic quality, were summed to obtain the desired indicator of institutional quality following Bekaert et al. (2005). Economic performance was measured by real GDP, and financial development was measured by domestic credit to private sector as a ratio of GDP. Trade openness was measured by total exports and imports as a ratio of GDP, urbanization was measured by urban population as a ratio of overall population, and energy consumption was measured by fossil fuel consumption which included coal, oil, petroleum, and natural gas products. The remaining control variables were all obtained from World Development Indicators (WDI CD ROM 2015). The scatter plot as reported in Fig. 3 in the Appendix shows that the relationship between the two main variables of carbon emissions and institutional quality was positive although it looks ambiguous because the plotting is not straight.

\section{Empirical results and discussions}

Table 1 highlights the descriptive statistics of the variables and shows the number of observations, the mean, standard deviation, and the minimum and maximum of the original data for the variables. For example, the mean for the two key variables of carbon dioxide emissions and institutional quality was 1.989 and 6.873 , respectively.

The correlation matrix above shows that the variables of institutional quality, financial development, economic growth, trade openness, urbanization, and energy consumption have a positive and significant correlation with the dependent variable (carbon dioxide emissions) as presented in Table 2.

Before estimating the dynamic panel GMM model, the main model for this study, the static panel models for fixed and random effects were estimated and their results were reported in Table 3. The finding shows that there was no any significant relationship between institutional quality and carbon dioxide emissions across the sample countries. However, the variables of trade openness, urbanization, and energy consumption had a positive relationship with carbon dioxide emissions, which means that increase in these variables substantially will lead to more carbon dioxide emissions. The Hausman test, which is based on the $p$ value (0.057), shows that the null hypothesis cannot be rejected, which means that the random effect model was more appropriate than the fixed effect model. The result for the main hypothesis (impact of institutional quality on environmental quality) is insignificant, which might be due to the static nature of the model. Hence, we applied the dynamic panel model to see whether there might then be a variation of the outcome since the dynamic panel models are considered to be more efficient and robust than the traditional static panel model.

Moving to the Arellano and Bond (1991) and the Arellano and Bover (1995) dynamic panel GMM model is reported in Table 4 below. We reported both difference and system GMM estimators in Table 4, but since system GMM is considered more robust and efficient than the difference GMM, our analysis mainly relied on the system GMM results. Models I and II have a one-step and two-step difference GMM, respectively, while models III and IV are used for a one-and two-step system GMM respectively. The main finding based on the system GMM reveals that quality institutions help in reducing the amount of carbon dioxide emissions. It also shows that institutional quality has a negative and significant impact on carbon dioxide emissions. This finding means that a $1 \%$ increase in institutional quality tends to reduce carbon dioxide emissions by $0.313 \%$ in the sample countries. This finding is consistent with that of Lau et al. (2014) and Al-mulali and Ozturk 
Table 1 Descriptive statistics for the variables

\begin{tabular}{lllllll}
\hline Variables & Observation & Mean & Std-dev & Minimum & Maximum & Unit of measurements \\
\hline $\begin{array}{lllll}\text { Carbon dioxide emissions } \\
\text { Institutional quality }\end{array}$ & 322 & 1.989 & 2.112 & 0.039 & 9.545 & O $_{2}$ emissions metric tons per capita \\
& 329 & 6.873 & 1.657 & 2.500 & 12.417 & $\begin{array}{c}\text { Corruption, rule of law, and bureaucratic quality } \\
\text { (scaled 1-30) }\end{array}$ \\
Economic growth & 329 & 1.260 & 2.400 & 2.090 & 1.240 & Real GDP \\
Financial development & 329 & 35.662 & 25.168 & 1.095 & 160.124 & Domestic credit to private sector as a ratio of GDP \\
Trade openness & 329 & 77.909 & 35.517 & 22.118 & 210.374 & Total exports and imports as a ratio of GDP \\
Urbanization & 329 & 52.661 & 18.060 & 15.504 & 88.769 & Urban population as a ratio of overall population \\
Energy consumptions & 329 & 59.921 & 29.829 & 2.275 & 99.848 & Fossil fuel consumptions \\
\hline
\end{tabular}

(2015) who found that quality institutions reduce carbon dioxide emissions in Malaysia and MENA countries, respectively. The empirical results further show that the variables of economic performance, trade openness, urbanization, and energy consumption have a positive and significant impact on carbon dioxide emissions. This means that a $1 \%$ increase in economic performance, trade openness, urbanization, and energy consumption could increase the level of carbon dioxide emissions by $0.195 \%, 0.194 \%, 1.599 \%$, and $0.304 \%$, respectively. However, financial development did not have any significant impact on carbon dioxide emissions in the sample countries.

The post-estimation tests of the models were also valid as we could not reject the null hypothesis for Sargan/Hansen which means the instruments were valid. The second order serial correlation $\operatorname{AR}(2)$, which is meant to check $\operatorname{AR}(1)$, was also valid. This mean was consistent with the GMM econometric theory. However, the main result was insignificant, as quality of institutions did not have any significant impact on carbon dioxide emissions in the sample countries when difference GMM was applied. Moreover, as earlier mentioned since system GMM was considered a more robust and efficient estimator compared to difference GMM, our analysis mainly relies on the findings of system GMM.

Table 2 Correlations matrix of the variables

\begin{tabular}{llllllll}
\hline & 푁2 & INQ & $Y$ & FD & TO & UB & EC \\
\hline 푁2 & 1.0000 & & & & & & \\
INQ & 0.1512 & 1.0000 & & & & & \\
$Y$ & 0.2002 & 0.2218 & 1.0000 & & & & \\
FD & 0.5353 & 0.2918 & 0.1426 & 1.0000 & & & \\
TO & 0.2834 & 0.1465 & -0.3247 & 0.3368 & 1.0000 & & \\
UB & 0.5127 & 0.0156 & 0.2081 & 0.2560 & 0.1503 & 1.0000 & \\
EC & 0.6004 & 0.4213 & 0.2225 & 0.4145 & 0.2701 & 0.5457 & 1.0000
\end{tabular}

퓍 2 , carbon dioxide emissions; $I N Q$, institutional quality; $Y$, economic growth; $F D$, financial development; $T O$, trade openness; $U B$, urbanization; $E C$, energy consumption. $* p<0.05, * * p<0.01$, and $* * * p<0.001$ denote significant at $5 \%, 10 \%$, and $1 \%$ respectively. The $R$ coefficient is of Pearson correlation

\section{Robustness checks}

As the scatter plot (refer to Appendix (Fig. 4)) shows, some countries move far away from the main sample, so we conducted Cook's outlier test as advocated by Cook (1977) to detect any country with high leverage or large residuals. Some counties were found to have outliers, so we dropped the outliers and re-estimated the models. The result as reported in Table 5 shows that even after removing all outliers from the sample, the main result remained consistent with what was obtained in the full sample as system GMM results. This means that institutional quality does reduce carbon dioxide emissions in the sample countries. That is to say, a $1 \%$ increase in institutional quality could lead to the reduction of carbon dioxide emissions by $0.206 \%$. The remaining control variables also revealed that economic performance could lead to the reduction of carbon dioxide emission, hence improve environmental quality. Statistically, it revealed that a $1 \%$

Table 3 Institutional quality and carbon emissions in developing countries: fixed and random effect models

\begin{tabular}{|c|c|c|}
\hline Variables & Fixed effect & Random effect \\
\hline Institutional quality & $0.022(0.050)$ & $0.005(0.050)$ \\
\hline Economic growth & $0.075(0.054)$ & $0.069(0.043)$ \\
\hline $\begin{array}{l}\text { Financial } \\
\text { development }\end{array}$ & $-0.000(0.021)$ & $-0.004(0.020)$ \\
\hline Trade openness & $0.057 *(0.038)$ & $0.067 *(0.038)$ \\
\hline Urbanization & $0.606 * * *(0.191)$ & $0.773 * * *(0.156)$ \\
\hline Energy consumption & $0.522 * * *(1.091)^{*}$ & $0.577 * * *(0.963)$ \\
\hline $\begin{array}{l}\text { Number of } \\
\text { observations }\end{array}$ & 320 & 320 \\
\hline Sample period & 2004-2010 & 2004-2010 \\
\hline $\begin{array}{l}\text { Number of time } \\
\text { period }(T)\end{array}$ & 7 & 7 \\
\hline $\begin{array}{l}\text { Number of } \\
\text { countries }(N)\end{array}$ & 47 & 47 \\
\hline Hausman test & \multicolumn{2}{|c|}{$\begin{array}{l}12.20 \\
(0.057)\end{array}$} \\
\hline
\end{tabular}

$* p<0.05, * * p<0.01$, and $* * * p<0.001$ denote significant at $5 \%, 10 \%$, and $1 \%$ respectively. Figures in parentheses are standard errors 
Table 4 Institutional quality and carbon dioxide emissions in developing countries: dynamic panel GMM estimation

\begin{tabular}{|c|c|c|c|c|}
\hline Variables & Model I & Model II & Model III & Model IV \\
\hline Lagged-dependent variable & $-0.198 * * *(0.075)$ & $-0.246 * * *(0.030)$ & $-0.047(0.071)$ & $-0.177 * * *(0.040)$ \\
\hline Institutional quality & $0.048(0.173)$ & $0.055(0.065)$ & $-0.435 * * *(0.160)$ & $-0.313 * *(0.131)$ \\
\hline Economic growth & $0.364 * * *(0.089)$ & $0.365 * * *(0.081)$ & $0.245 * * *(0.037)$ & $0.195 * * *(0.056)$ \\
\hline Financial development & $-0.029(0.037)$ & $-0.029(0.026)$ & $-0.108 * * *(0.028)$ & $-0.032(0.028)$ \\
\hline Trade openness & $0.300 * * *(0.094)$ & $0.189 * *(0.078)$ & $0.307 * * *(0.115)$ & $0.194 * *(0.087)$ \\
\hline Urbanization & $0.321(0.298)$ & $0.502 *(0.302)$ & $1.784 * * *(0.222)$ & $1.599 * * *(0.343)$ \\
\hline Energy consumption & $0.019(0.152)$ & $0.065(0.113)$ & $0.194(0.172)$ & $0.304 * *(0.151)$ \\
\hline Number of observations & 230 & 230 & 276 & 276 \\
\hline Sample period & 2004-2010 & 2004-2010 & 2004-2010 & 2004-2010 \\
\hline Number of time period $(T)$ & 7 & 7 & 7 & 7 \\
\hline Number of countries $(N)$ & 47 & 47 & 47 & 47 \\
\hline Number of instruments & 28 & 28 & 29 & 29 \\
\hline Sargan test ( $p$ value) & $16.47(0.742)$ & $16.47(0.742)$ & $46.11(0.001)$ & $46.11(0.001)$ \\
\hline Hansen test ( $p$ value) & - & $17.15(0.702)$ & - & $13.70(0.882)$ \\
\hline $\operatorname{AR}(2)$ & $-1.01(0.312)$ & $-0.70(0.486)$ & $0.03(0.974)$ & $-0.42(0.673)$ \\
\hline
\end{tabular}

$* p<0.05, * * p<0.01$, and $* * * p<0.001$ denote significant at $5 \%, 10 \%$, and $1 \%$ respectively. The dynamic panel GMM estimator of Arellano and Bond (1991) is applied for the difference GMM estimations and the Arellano and Bover (1995) is used for system GMM estimations. The two models are based on two steps. Figures in parentheses are standard errors. All variables are in logarithm form, and the estimations are based on xtabond 2 Roodman (2009) simulation study

increase in economic performance could reduce carbon dioxide emissions by $0.035 \%$. That result further highlights that a $1 \%$ increase in energy consumption could boost carbon dioxide emission by $0.411 \%$. Thus, energy consumption increases carbon dioxide emission and indirectly depletes environmental quality in the sample countries in the study.

\section{Conclusion and policy recommendations}

This study empirically examined the dynamic impact of institutional quality on carbon dioxide emissions across 47 developing countries, using dynamic panel GMM estimations. The empirical finding reveals that institutional quality
Table 5 Institutional quality and carbon dioxide emissions in developing countries: dynamic panel GMM estimation after removing outliers

\begin{tabular}{lll}
\hline Variables & Model I (Dif. GMM) & Model II (Sys. GMM) \\
\hline Lagged-dependent variable & $0.145^{* *}(0.056)$ & $0.751^{* * *}(0.030)$ \\
Institutional quality & $-0.088^{* *}(0.037)$ & $-0.206^{* * *}(0.041)$ \\
Economic growth & $0.290^{* * *}(0.048)$ & $-0.035^{*}(0.018)$ \\
Financial development & $-0.065^{* * *}(0.019)$ & $0.003(0.015)$ \\
Trade openness & $0.199 * * *(0.027)$ & $0.030(0.032)$ \\
Urbanization & $0.303(0.213)$ & $0.046(0.087)$ \\
Energy consumption & $0.540(0.036)$ & $0.411^{* * *}(0.053)$ \\
Number of observations & 210 & 252 \\
Sample period & $2004-2010$ & $2004-2010$ \\
Number of time period $(T)$ & 7 & 7 \\
Number of countries $(N)$ & 42 & 42 \\
Number of instruments & 38 & 36 \\
Sargan test $(p$ value) & $-0.824(0.409)$ & $27.446(0.149)$ \\
Hansen test $(p$ value $)$ & $9.29(0.406)$ & $21.30(0.238)$ \\
AR(2) & $17.656(0.963)$ & $0.165(0.868)$ \\
\hline
\end{tabular}

${ }^{*} p<0.05, * * p<0.01$, and $* * * p<0.001$ denote significant at $5 \%, 10 \%$, and $1 \%$ respectively. The dynamic panel GMM estimator of Arellano and Bond (1991) is applied for the difference GMM estimations and the Arellano and Bover (1995) is used for system GMM estimations. The two models are based on two steps. Figures in parentheses are standard errors. All variables are in logarithm form, and the estimations are based on xtabond2 Roodman (2009) simulation study 
reduces carbon dioxide emissions and hence reduces the level of environmental degradation in the countries that were investigated. This finding means that better and more quality institutions will help enhance the level of environmental quality. The finding based on the other control variables reveals that an increase in economic performance, trade openness, urbanization, and energy consumption positively influenced carbon dioxide emissions in the sample countries. The policy implication based on this finding is that, for developing countries to reduce environmental degradation caused by pollution that emanates from carbon dioxide emissions, it is essential for them to strengthen their institutions and then allow them to work effectively. Effective functioning of institutions in these countries will deliver proper laws, regulations, and property rights as well as ways to combat corruption, which if systematically followed, will reduce carbon dioxide emissions, and improve the level of environmental conditions in the countries investigated in this study. Moreover, governments in the selected sample countries should try to adopt proper legislations that could encourage green energy consumption which have little environmental problems.

\section{Appendix 1}

Fig. 3 Scatter plot of carbon dioxide emissions and institutional quality (2004-2010)

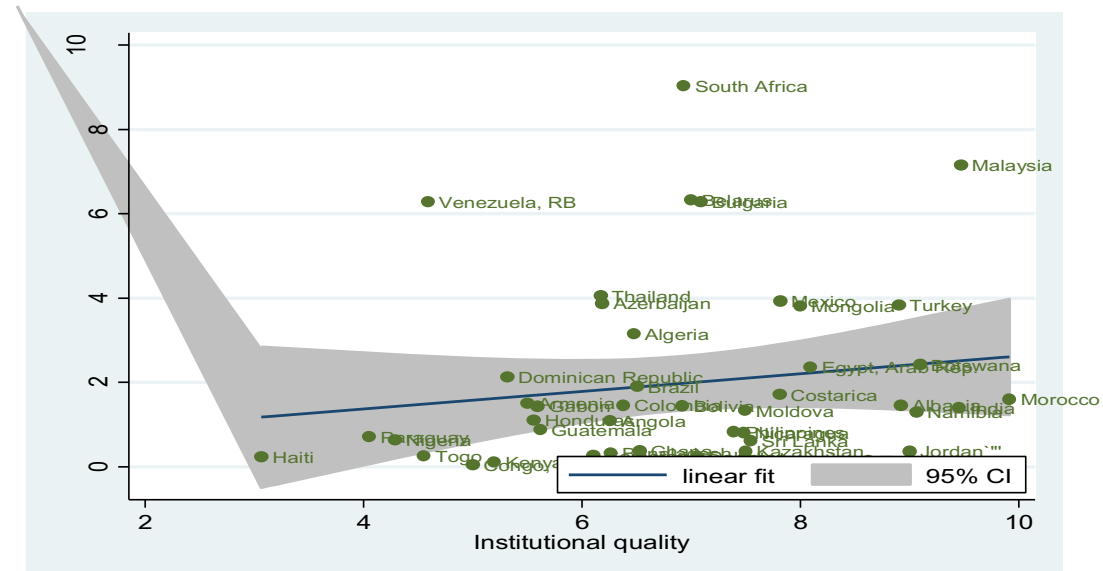

\section{Appendix 2}

\begin{tabular}{llr}
\hline S/N & Country & d1 \\
\hline 13 & Congo Dem. Rep & 0.3191507 \\
26 & Jordan & 0.1711121 \\
30 & Moldova & 0.1585734 \\
34 & Nigeria & 0.1429983 \\
\hline
\end{tabular}

d1 shows high leverage or large residuals of the countries

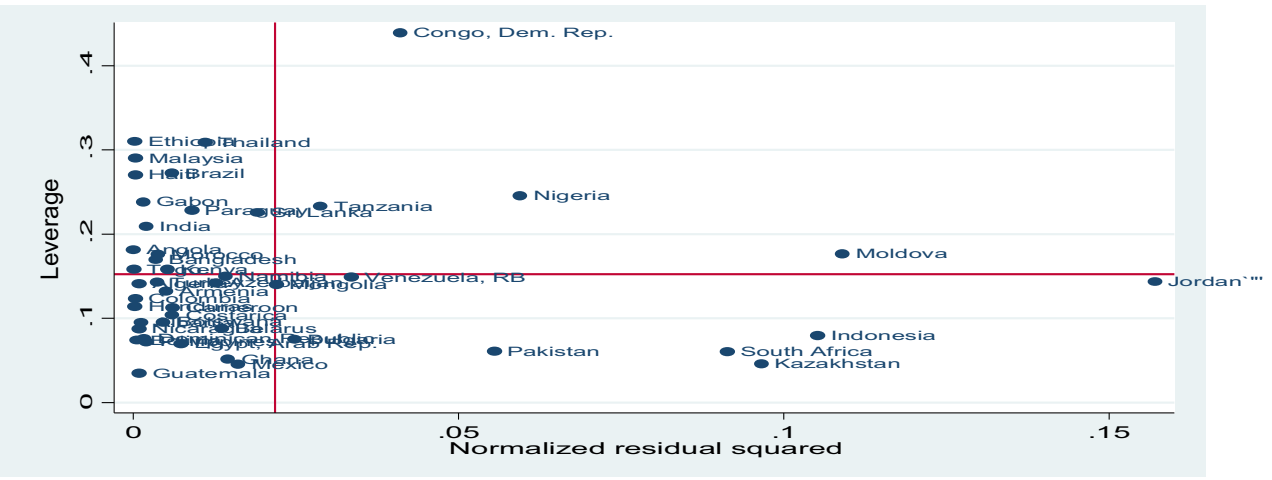




\section{References}

Ahmed K, Bhattacharya M, Shaikh Z, Ramzan M, Ozturk I (2017a) Emission intensive growth and trade in the era of the Association of Southeast Asian Nations (ASEAN) integration: an empirical investigation from ASEAN-8. J Clean Prod 154:530-540

Ahmed K, Rehman MU, Ozturk I (2017b) What drives carbon dioxide emissions in the long-run? Evidence from selected South Asian Countries. Renew Sust Energ Rev 70:1142-1153

Alam MM, Murad MW, Noman AHM, Ozturk I (2016) Relationships among carbon emissions, economic growth, energy consumption and population growth: testing Environmental Kuznets Curve hypothesis for Brazil, China, India and Indonesia. Ecol Indic 70:466-479

Ali HS, Law SH, Zannah TI (2016) Dynamic impact of urbanization, economic growth, energy consumption, and trade openness on $\mathrm{CO}$ 2 emissions in Nigeria. Environ Sci Pollut Res 23(12):12435-12443

Ali HS, Abdul-Rahim AS, Ribadu MB (2017) Urbanization and carbon dioxide emissions in Singapore: evidence from the ARDL approach. Environ Sci Pollut Res 24(2):1967-1974

Al-Mulali U, Ozturk I (2015) The effect of energy consumption, urbanization, trade openness, industrial output, and the political stability on the environmental degradation in the MENA (Middle East and North African) region. Energy 84:382-389

Al-mulali U, Tang CF, Ozturk I (2015a) Does financial development reduce environmental degradation? Evidence from a panel study of 129 countries. Environ Sci Pollut Res:1-10

Al-Mulali U, Ozturk I, Lean HH (2015b) The influence of economic growth, urbanization, trade openness, financial development, and renewable energy on pollution in Europe. Nat Hazards 79(1):621-644

Arellano M, Bond S (1991) Some tests of specification for panel data: Monte Carlo evidence and an application to employment equations. Rev Econ Stud 58(2):277-297

Arellano M, Bover O (1995) Another look at the instrumental variable estimation of error-components models. J Econ 68(1):29-51

Arouri MEH, Youssef AB, M'henni H, Rault C (2012) Energy consumption, economic growth and $\mathrm{CO} 2$ emissions in Middle East and North African countries. Energy Policy 45:342-349

Asongu S, El Montasser G, Toumi H (2016) Testing the relationships between energy consumption, $\mathrm{CO} 2$ emissions, and economic growth in 24 African countries: a panel ARDL approach. Environ Sci Pollut Res 23(7):6563-6573

Balibey M (2015) Relationships among CO2 emissions, economic growth and foreign direct investment and the EKC hypothesis in Turkey. Int J Energy Econ Policy 5(4):1042-1049

Baltagi BH (2005) Econometric analysis of panel data. John Wiley, Chichester

Bekaert G, Harvey CR, Lundblad C (2005) Does financial liberalization spur growth? J Financ Econ 77(1):3-55

Cook RD (1977) Detection of influential observation in linear regression. Technometrics:15-18

Dean JM, Lovely ME, Wang H (2009) Are foreign investors attracted to weak environmental regulations? Evaluating the evidence from China. J Dev Econ 90(1):1-13

Egbetokun SO, Ogundipe AA (2016) Attaining EKC in Africa: why institutions really matter. Res J Appl Sci 11(9):884-890. https:// doi.org/10.3923/rjasci.2016.884.890

Farhani S, Ozturk I (2015) Causal relationship between CO2 emissions, real GDP, energy consumption, financial development, trade openness, and urbanization in Tunisia. Environ Sci Pollut Res 22(20): 15663-15676

Ibrahim MH, Law SH (2015) Institutional quality and CO2 emission-trade relations: evidence from Sub-Saharan Africa. South African Journal of Economics 84:323-340. https://doi.org/10.1111/saje.12095
Lau LS, Choong CK, Eng YK (2014) Carbon dioxide emission, institutional quality, and economic growth: empirical evidence in Malaysia. Renew Energy 68:276-281

Merican Y (2007) Foreign direct investment and pollution in five Asean nations. International Journal of Economics \& Management 1(2):24261

Nickell S (1981) Biases in dynamic models with fixed effects. Econometrica 49:1417-1426

Ozturk I (2015) Measuring the impact of energy consumption and air quality indicators on climate change: evidence from the panel of UNFCC classified countries. Environ Sci Pollut Res 22(20): $15459-15468$

Pao HT, Tsai CM (2011) Multivariate Granger causality between CO 2 emissions, energy consumption, FDI (foreign direct investment) and GDP (gross domestic product): evidence from a panel of BRIC (Brazil, Russian Federation, India, and China) countries. Energy 36(1):685-693

Paramati SR, Sinha A, Dogan E (2017) The significance of renewable energy use for economic output and environmental protection: evidence from the Next 11 developing economies. Environ Sci Pollut Res:1-15

Ponce de Leon Barido D, Marshall JD (2014) Relationship between urbanization and $\mathrm{CO} 2$ emissions depends on income level and policy. Environ Sci Technol 48(7):3632-3639

Ren S, Yuan B, Ma X, Chen X (2014) International trade, FDI (foreign direct investment) and embodied CO 2 emissions: a case study of Chinas industrial sectors. China Econ Rev 28:123-134

Roodman D (2009) A note on the theme of too many instruments. Oxf Bull Econ Stat 71(1):135-158

Salahuddin M, Gow J, Ozturk I (2015) Is the long-run relationship between economic growth, electricity consumption, carbon dioxide emissions and financial development in Gulf Cooperation Council Countries robust? Renew Sust Energ Rev 51:317-326

Salahuddin M, Khorshed A, Ilhan O, Sohag K (2017) The effects of electricity consumption, economic growth, financial development and foreign direct investment on $\mathrm{CO} 2$ emissions in Kuwait. Renew Sust Energ Rev Article in press

Seker F, Ertugrul HM, Cetin M (2015) The impact of foreign direct investment on environmental quality: a bounds testing and causality analysis for Turkey. Renew Sust Energ Rev 52:347-356

Shahbaz M, Sbia R, Hamdi H, Ozturk I (2014) Economic growth, electricity consumption, urbanization and environmental degradation relationship in United Arab Emirates. Ecol Indic 45:622-631

Sharma SS (2011) Determinants of carbon dioxide emissions: empirical evidence from 69 countries. Appl Energy 88(1):376-382

Sinha A, Shahbaz M, Balsalobre D (2017) Exploring the relationship between energy usage segregation and environmental degradation in N-11 countries. J Clean Prod. Article in press 168:1217-1229

United States Energy Information Administration (2016): Accessed on $20^{\text {th }}$ November, 2016 through the following link: https://www.eia. gov/outlooks/ieo/emissions.php

World Development Indicators (WDI) (2015): A World Bank data base Accessed on $17^{\text {th }}$ August, 2017 through: http://data.worldbank.org/ data-catalog/world-development-indicators

Zeng K, Eastin J (2012) Do developing countries invest up? The environmental effects of foreign direct investment from less-developed countries. World Dev 40(11):2221-2233

Zhang C, Zhou X (2016) Does foreign direct investment lead to lower $\mathrm{CO} 2$ emissions? Evidence from a regional analysis in China. Renew Sust Energ Rev 58:943-951

Publisher's note Springer Nature remains neutral with regard to jurisdictional claims in published maps and institutional affiliations. 